\title{
Mitigation of Copper Stress in Maize by Inoculation with Paenibacillus polymyxa and Bacillus circulans
}

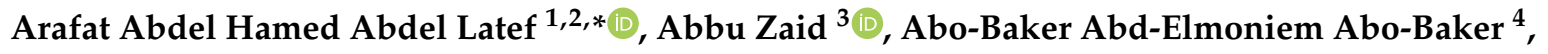 \\ Wesam Salem 2 and Mona Fawzy Abu Alhmad 2,5 \\ 1 Biology Department, Turabah University College, Turabah Branch, Taif University, P.O. Box 11099, \\ Taif 21944, Saudi Arabia \\ 2 Botany and Microbiology Department, Faculty of Science, South Valley University, Qena 83523, Egypt; \\ wesam.salem@svu.edu.eg (W.S.); mfmahmoud@tu.edu.sa (M.F.A.A.) \\ 3 Plant Physiology and Biochemistry Section, Department of Botany, Aligarh Muslim University, \\ Aligarh 202002, India; azaid@myamu.ac.in \\ 4 Department of Soils and Water Science, Faculty of Agriculture, South Valley University, Qena 83523, Egypt; \\ Bashaabobaker@yahoo.com \\ 5 Biology Department, Faculty of Science, Taif University, Al-Hawiyah, Taif 21944, Saudi Arabia \\ * Correspondence: a.moawd@tu.edu.sa or moawad76@gmail.com or arafat.moawad@sci.svu.edu.eg
}

Received: 15 October 2020; Accepted: 6 November 2020; Published: 8 November 2020

check for updates

\begin{abstract}
Copper $(\mathrm{Cu})$ is a micronutrient that assumes a principal role in plant growth and development. However, its excess concentration in soil is imperiling crop productivity. Inoculation with different bacterial strains in cereals could modify growth traits, photosynthetic effectiveness, and generation of strong antioxidant defense systems to make them more tolerant of $\mathrm{Cu}$ stress. Therefore, a pot study was designed to test plant growth-promoting rhizobacteria (PGPR) including Paenibacillus polymyxa and Bacillus circulans to $\mathrm{Cu}$ exposed maize (Zea mays L.) plants. Increasing $\mathrm{Cu}$ (100 to $500 \mu \mathrm{M}$ of $\mathrm{CuSO}_{4}$ ) concentration decreased growth traits, photosynthetic pigments, soluble sugars, phosphorous $(\mathrm{P})$ and potassium $(\mathrm{K})$ contents, and the activity of catalase (CAT) but increased proline and malondialdehyde (MDA) content, the activity of peroxidase (POD) and $\mathrm{Cu}$ ions at root and shoot level. Moreover, the bacterial treatment also modulated the antioxidant capability in stress-free plants. Nevertheless, inoculation with P. polymyxa and B. circulans alleviated $\mathrm{Cu}$-induced growth, photosynthetic pigments and mineral nutrient ( $\mathrm{P}$ and $\mathrm{K}$ ) on one hand and regulating the pools of osmolytes and antioxidant enzymes, whilst simultaneously reducing MDA and $\mathrm{Cu}$ root and shoot contents. These improved activities of antioxidant enzymes and the regulation of osmolytes content elicited by the blend of bacterial inoculation would have retained the ability of maize plants to confer resilience to $\mathrm{Cu}$ stress. This study further affirms that the application of two specific bacterial strains to maize plants proved very effective to ameliorate the $\mathrm{Cu}$ toxicity.
\end{abstract}

Keywords: antioxidant activities; Bacillus circulans; copper toxicity; maize; Paenibacillus polymyxa; plant growth-promoting rhizobacteria (PGPR)

\section{Introduction}

Due to changing environmental conditions, the problem of heavy metal (HM) stress in the plant-soil environment has resulted in a considerable reduction of growth and development of major crop plants worldwide [1-5]. Furthermore, pollution caused by HMs and improper fertilization practices poses a serious threat to a sustainable environment and healthy food. Copper is one of eight essential microelements and is an important part of the cofactor of various metalloproteins and other macromolecules involved in wide essential metabolic processes in plants including net photosynthesis, 
respiration, lignification of the cell wall, and various protective mechanisms [6-8]. However, owing to various anthropogenic activities, this HM has gained particular attention among plant stress physiologists due to its dual nature in the plant system: essential as well as toxic at an optimum and high level respectively $[9,10]$. An excess of $\mathrm{Cu}$ concentration in plant tissues induces oxidative stress via enhanced biosynthesis of various reactive oxygen species (ROS), resulting in damage to photosystem pigment proteins, DNA, RNA, lipids, enzymes, altered thylakoid membranes composition, decreased chlorophyll and mineral nutrient contents and hampered meristems development [11-15]. Hence, given its dual nature (essential as well as toxic), this HM could involve complex mechanisms of uptake, transport, sequestration and detoxification inside the plant tissues at the cellular level. However, several efforts have been made to counteract the $\mathrm{Cu}$-induced toxicity in diverse crop plants.

In recent times, as a result of the rising costs of chemical fertilizers as well as the related environmental risk and health issues associated with the use of such compounds, a severe degradation in soil fertility and a decrease in the quality of foods and their products have been observed. Therefore, the researchers' mentality has shifted to the use of biological solutions, such as microbial biotechnology to solve the HM-toxicity problems [16-18]. Moreover, there is a growing desire to understand modifications in microbial rhizosphere diversity and community structure under different environmental conditions. The rhizospheric microbes are typically classified into three types: useful, harmful, and inert [19] and play an important role in mitigating diverse plant biotic and abiotic pressures [20,21]. Plant growth-promoting rhizobacteria (PGPR) are agriculturally important in increasing plant growth and yield [22,23]. Several PGPRs have been evidenced to alleviate the toxicity of HM in crop plants. In addition, inoculation technology involving PGPR is recognized as a beneficial eco-friendly tool to optimize sustainability in agriculture and allied sectors due to its low costs and biological nature compared with other industrial inputs [17]. It has been reported that inoculation with two Bacillus isolates enhanced tolerance to salt, drought, and HM stresses in potato plants [24]. In soybean plants, Bacillus cereus, Bacillus megaterium, Trichoderma longibrachiatum and Trichoderma simmonsii boosted tolerance to simultaneous salt and drought stresses [25]. Staphylococcus arlettae strain MT4 has been shown to alleviate $\mathrm{Cr}$ toxicity in sunflower plants by restricting its uptake and strengthening the plant antioxidant defense system [26]. In pennyroyal, Azotobacter and Azospirillum strains increased the biosynthesis of secondary metabolites and imparted drought stress tolerance [27]. Moreover, the strain of Bacillus was found to diminish the stress induced by nanoparticles in mustard plants [28]. In alfalfa plants, salt tolerant PGPR enhanced salt stress tolerance under high salinity conditions [29]. In earlier reports, it has been concluded that maize seedlings inoculated with PGPR have shown tolerance to salt [30,31], Al and salt [32], Cd [33], drought [34] and chilling [35] stresses. Application of Bacillus siamensis to wheat plants showed improved tolerance to $\mathrm{Cd}$ stress by restricting the accumulation of $\mathrm{Cd}$ and boosting the antioxidant defense system [36]. However, research regarding underlying mechanisms of inoculation of maize plants with phosphate- and potassium-solubilizing bacterial strains P. polymyxa and B. circulans under $\mathrm{Cu}$ toxicity receive little attention.

Maize (Zea mays L.) is an important cereal crop cultivated worldwide and exhibits strong potential for the phytoremediation of HM contaminated soils [37,38]. Earlier studies also reported the toxic impact of $\mathrm{Cu}$ on maize plants [39-43]. However, more detailed studies should be done to obtain a precise nature of PGPR mediated $\mathrm{Cu}$ stress tolerance in maize plants involving various biochemical and physiological abilities. With this aim, the present study was undertaken.

\section{Materials and Methods}

\subsection{Bacterial Inoculation and Experimental Design}

Two phosphate- and potassium-solubilizing bacterial strains Paenibacillus polymyxa and Bacillus circulans were utilized in the present study. P. polymyxa was locally isolated [44] whereas B. circulans was obtained from Microbial Resource Centre, Faculty of Agriculture, Ain Shams University, Egypt. Maize seeds (Zea mays L. cv. single hybrid 10) were first treated in $\mathrm{NaOCl}(10 \%, \mathrm{v} / \mathrm{v})$ for $4 \mathrm{~min}$ 
followed by repeated washings with double distilled water (DDW) for five times. The bacteria $\left(6 \times 10^{6}\right.$ $\mathrm{cfu} / \mathrm{gm}$ ) were inoculated at the rate of $10 \%$ of the weight of maize seed and mixed thoroughly until the seeds were found to be uniformly surface coated with bacterial strains [45-48]. After inoculation, the sterilized maize seeds were sown in plastic pots ( 5 seeds per pot). The pots contained $2 \mathrm{~kg}$ of an autoclaved dry clay soil. There were three replicates per treatment $(n=3)$ and the plastic pots were arranged into completely randomized block design in a factorial arrangement. In total there were nine treatments: (i) Control, plants without copper stress and bacterial strains inoculation; (ii) $\mathrm{Cu} 1$ : plants exposed to $100 \mu \mathrm{M} \mathrm{CuSO}_{4}$; (iii) $\mathrm{Cu}$ 2: plants exposed to $500 \mu \mathrm{M} \mathrm{CuSO}_{4}$; (iv) P. polymyxa ( $P p$ ) inoculated plants without $\mathrm{CuSO}_{4}$; (v) $\mathrm{Cu} 1+P p$ : plants exposed to $100 \mu \mathrm{MCuSO}_{4}$ and inoculated with P. polymyxa; (vi) $\mathrm{Cu} 2+P p$ : plants exposed to $500 \mu \mathrm{MCuSO}_{4}$ and inoculated with P. polymyxa; (vii) B. circulans (Bc) inoculated plants without $\mathrm{CuSO}_{4}$; (viii) $\mathrm{Cu} 1+B c$ : plants exposed to $100 \mu \mathrm{MCuSO}_{4}$ and inoculated with B. circulans; (ix) $\mathrm{Cu} 2+B c$ : plants exposed to $500 \mu \mathrm{M} \mathrm{CuSO}_{4}$ and inoculated with B. circulans. Copper in the form of copper sulfate $\left(\mathrm{CuSO}_{4} \cdot 5 \mathrm{H}_{2} \mathrm{O}, 99 \%\right.$ purity, Sigma-Aldrich, St. Louis, MO, USA) was given as the point of supply of $\mathrm{Cu}$ stress through the soil at different doses of 100 or $500 \mu \mathrm{M}$ at 10 days after sowing (DAS). From the first DAS, the pots of all the treatments were given $400 \mathrm{~mL}$ DDW as and when required. The experimental pots were placed under field conditions with a day length of $10-12 \mathrm{~h}$, mean temperatures of $35 / 22^{\circ} \mathrm{C}$, and relative humidity of $55-67 \%$ in the wire-house of the experimental farm of the South Valley University, Qena, Egypt. After 25 days of seed germination, maize plants were harvested for examining different growth and physio-biochemical traits as follows.

\subsection{Growth Parameters}

After harvesting, the fresh weight (FW) of maize plants was measured. The maize seedlings were then oven-dried at a constant weight and the dry weight (DW) was estimated. The leaf area (LA) of maize seedlings was estimated using a planimeter (SOKKIA Planimeter KP-90, London, UK).

\subsection{Photosynthetic Pigment Analysis}

The photosynthetic pigments viz-chlorophyll (Chl a and b) and carotenoids (Caro) were determined by adopting Lichtenthaler and Wellburn [49] protocol. Fresh leaf material (100 mg) was pelleted in a pre-chilled mortar with $4 \mathrm{~mL}$ of acetone solution $(80 \%, \mathrm{v} / \mathrm{v})$. The slurry was centrifuged at $3000 \mathrm{rpm}$ for $5 \mathrm{~min}$. The pellet was discarded and the absorbances of resulted supernatants were measured spectrophotometrically at 663, 645, and $470 \mathrm{~nm}$ for determining the $\mathrm{Chl} \mathrm{a}, \mathrm{b}$ and Caro respectively against the acetone $(80 \%, \mathrm{v} / \mathrm{v})$ taken as blank.

\subsection{Osmolyte Contents}

The protocol of Irigoyen et al. [50] was adopted to estimate soluble sugars content. The content of soluble proteins was determined by following the Bradford [51] method. For the determination of proline, the protocol of Bates et al. [52] was followed.

\subsection{Determination of Malondialdehyde (MDA)}

For MDA content determination, the thiobarbituric acid (TBA) reaction method described by Zhang and Qu, [53] was adopted. The complete experimental guide has already been given by Abdel Latef and Tran [54].

\subsection{Antioxidant Enzymes Activity}

The freshly collected leaf samples were harvested for the determination of various antioxidant enzyme activities including catalase (CAT; EC 1.11.1.6), peroxidase (POD; EC 1.11.1.7) and ascorbate peroxidase (APX; EC 1.11.1.11). The leaf tissue was taken in the pre-chilled mortar with liquid $\mathrm{N}_{2}$. After that, the enzymatic extraction was performed according to the method of Ahmad et al. [55]. The CAT activity was determined as per the protocol of Aebi [56]. The procedure proposed by Maehly 
and Chance [57] was used for the POD activity determination. The method of Chen and Asada [58] was utilized for the determination of APX activity. The detailed antioxidant enzymes' procedure is described in Abdel Latef et al. [48].

\subsection{Estimation of Phosphorous (P), Potassium (K) and Copper Contents}

The dried seedling samples were acid digested for $12 \mathrm{~h}$ in $80 \%$ perchloric acid and concentrated $\mathrm{H}_{2} \mathrm{SO}_{4}$ solutions (1:5) at $140-160{ }^{\circ} \mathrm{C}$. After that, the samples were cooled and diluted with $1 \mathrm{M} \mathrm{HCl}$. Blanks were prepared without the samples. The procedure for determining $\mathrm{K}$ content was adopted by Williams and Twine [59] and the content of $P$ was calculated using ammonium molybdate blue based on Allen [60] procedure.

The root and shoot samples were dried at $85^{\circ} \mathrm{C}$ for $24 \mathrm{~h}$, digested in a tri-acid $\left(\mathrm{H}_{2} \mathrm{SO}_{4}, \mathrm{HNO}_{3}\right.$, $\mathrm{HCLO}_{4}$ ) mixture at the ratio of 5:1:1 v/v. Drops of $\mathrm{HNO}_{3}$ and $\mathrm{H}_{2} \mathrm{O}_{2}$ were added to make the solution transparent. The $\mathrm{Cu}$ content of root and shoot was determined by atomic absorption spectrophotometer.

\subsection{Statistical Analysis}

Data were analyzed by the analysis of variance (ANOVA) with SAS software (Version 9.1; SAS Institute, Cary, NC, USA), and Duncan's multiple range test was calculated at the 0.05 level of significance $(p<0.05)$. Data shown in the figures are the mean \pm standard deviation (SD) of three independent replicates. Principal component analysis (PCA) was done by Minitab software by employing Minitab Release 19.2.0 statistical software.

\section{Results}

\subsection{Inoculation with Bacteria Improves Growth Traits under $\mathrm{Cu}$ Stress}

The weights (fresh and dry) of maize seedlings were decreased under both $\mathrm{Cu}(100$ and $500 \mu \mathrm{M})$ doses versus control. The inoculation with $P p$ and $B c$ increased the FW and DW under stress-free conditions compared to controls. Inoculation with $P p$ and $B c$ provoked a significant increase in plants receiving $\mathrm{Cu} 1$ and 2 doses in FW and DW compared to $\mathrm{Cu} 1$ and 2 plants respectively (Table 1 ).

Table 1. Effects of bacterial inoculation under copper stress on fresh weight $\left(\mathrm{g} \mathrm{plant}^{-1}\right)(\mathrm{b}) \mathrm{dry}$ weight $\left(\mathrm{g}_{\text {plant }}{ }^{-1}\right)$ and $(\mathrm{c})$ leaf area $\left(\mathrm{cm}^{2}\right.$ plant $\left.^{-1}\right)$ in maize plants. Bars represent the standard deviation $( \pm \mathrm{SD})$ of the means $(n=3)$. Different letters indicate significant differences among the treatments at $p<0.05$, according to Duncan's multiple range test. The treatments include Control, plants without copper stress and bacterial strains inoculation; $\mathrm{Cu} 1$ : plants exposed to $100 \mu \mathrm{M} \mathrm{CuSO}_{4} ; \mathrm{Cu} 2$ : plants exposed to $500 \mu \mathrm{M} \mathrm{CuSO}_{4} ;$ P. polymyxa (Pp) inoculated plants without $\mathrm{CuSO}_{4} ; \mathrm{Cu} 1+P p$ : plants exposed to $100 \mu \mathrm{M}$ $\mathrm{CuSO}_{4}$ and inoculated with $P$. polymyxa; $\mathrm{Cu} 2+P p$ : plants exposed to $500 \mu \mathrm{M} \mathrm{CuSO}_{4}$ and inoculated with P. polymyxa; B. circulans (Bc) inoculated plants without $\mathrm{CuSO}_{4} ; \mathrm{Cu} 1+B c$ : plants exposed to 100 $\mu \mathrm{M} \mathrm{CuSO}_{4}$ and inoculated with $B$. circulans and $\mathrm{Cu} 2+B c$ : plants exposed to $500 \mu \mathrm{M} \mathrm{CuSO}_{4}$ and inoculated with B. circulans.

\begin{tabular}{|c|c|c|c|}
\hline Treatments & Fresh Weight & Dry Weight & Leaf Area \\
\hline Control & $5.39 \pm 0.27^{\mathrm{c}}$ & $0.46 \pm 0.02^{c}$ & $23.06 \pm 0.14^{\mathrm{e}}$ \\
\hline Cu 1 & $4.77 \pm 0.10^{\mathrm{d}}$ & $0.40 \pm 0.02^{\mathrm{d}}$ & $22.33 \pm 0.11^{f}$ \\
\hline $\mathrm{Cu} 2$ & $3.28 \pm 0.05^{f}$ & $0.26 \pm 0.03^{f}$ & $8.71 \pm 0.14^{i}$ \\
\hline$P p$ & $6.70 \pm 0.15^{\mathrm{a}}$ & $0.61 \pm 0.01^{\mathrm{a}}$ & $27.51 \pm 0.06^{\mathrm{a}}$ \\
\hline $\mathrm{Cu} 1+P p$ & $5.26 \pm 0.14^{c}$ & $0.47 \pm 0.02^{c}$ & $26.61 \pm 0.08^{b}$ \\
\hline $\mathrm{Cu} 2+P p$ & $4.87 \pm 0.09^{\mathrm{d}}$ & $0.41 \pm 0.02^{\mathrm{d}}$ & $14.48 \pm 0.14 \mathrm{~g}$ \\
\hline$B c$ & $6.20 \pm 0.11^{b}$ & $0.54 \pm 0.02^{b}$ & $25.24 \pm 0.08^{c}$ \\
\hline $\mathrm{Cu} 1+B c$ & $5.15 \pm 0.12^{c}$ & $0.43 \pm 0.02 \mathrm{~cd}$ & $24.37 \pm 0.08^{d}$ \\
\hline $\mathrm{Cu} 2+B c$ & $4.40 \pm 0.13^{\mathrm{e}}$ & $0.36 \pm 0.02 \mathrm{e}^{\mathrm{e}}$ & $12.53 \pm 0.22^{h}$ \\
\hline
\end{tabular}


A negative effect in the case of the LA of maize seedlings was noticed under $\mathrm{Cu} 1$ and 2 conditions compared to control plants. The plants inoculated with $P p$ and $B c$ caused a marked increase in LA and the maximum increase was noticed under stress-free conditions with $P p$ compared to control plants. The $B c$ and $P p$ inoculated plants grown under both $\mathrm{Cu}$ doses also recorded a significant increase in LA over $\mathrm{Cu} 1$ and 2 plants (Table 1 ).

\subsection{Bacterial Inoculation under $C u$ Doses Increases the Contents of Chlorophyll $a, b$ and Carotenoids}

The content of $\mathrm{Chl} a$ was decreased under both $\mathrm{Cu} 1$ and $\mathrm{Cu} 2$ concentrations against controls but this decrease was more pronounced in the $\mathrm{Cu} 2$ dose. The $P p$ and $B c$ inoculation increased the Chl $a$ content under non-stress conditions relative to control plants. In the case of $\mathrm{Cu} 1$ conditions, the inoculation with $P p$ and $B c$ maximally improved the $\mathrm{Chl} a$ in comparison to $\mathrm{Cu} 1$ alone plants, whereas, a smaller increase was noticed in $\mathrm{Cu} 2$ plants inoculated with $P p$ and $B c$, respectively compared to $\mathrm{Cu} 2$ alone plants (Table 2).

Table 2. Effects of bacterial inoculation under copper stress on chlorophyll a (Chl $a)$, chlorophyll b $(\mathrm{Chl} b)$, carotenoids (Caro), soluble sugars, soluble proteins, proline ( $\mathrm{mg} \mathrm{g}^{-1}$ fresh weight (FW)), and malondialdehyde (MDA; $\mathrm{nmol} \mathrm{g}^{-1} \mathrm{FW}$ ) contents in maize plants. Bars represent the standard deviation $( \pm \mathrm{SD})$ of the means $(n=3)$. Different letters indicate significant differences among the treatments at $p<0.05$, according to Duncan's multiple range test. The treatments include Control, plants without copper stress and bacterial strains inoculation; $\mathrm{Cu} 1$ : plants exposed to $100 \mu \mathrm{M} \mathrm{CuSO}_{4} ; \mathrm{Cu} 2$ : plants exposed to $500 \mu \mathrm{M} \mathrm{CuSO}_{4} ;$ P. polymyxa (Pp) inoculated plants without $\mathrm{CuSO}_{4} ; \mathrm{Cu} 1+P p$ : plants exposed to $100 \mu \mathrm{M} \mathrm{CuSO}_{4}$ and inoculated with P. polymyxa; Cu $2+P p$ : plants exposed to $500 \mu \mathrm{M}$ $\mathrm{CuSO}_{4}$ and inoculated with P. polymyxa; B. circulans $(B c)$ inoculated plants without $\mathrm{CuSO}_{4} ; \mathrm{Cu} 1+B c$ : plants exposed to $100 \mu \mathrm{M} \mathrm{CuSO}_{4}$ and inoculated with $B$. circulans and $\mathrm{Cu} 2+B c$ : plants exposed to $500 \mu \mathrm{M} \mathrm{CuSO}_{4}$ and inoculated with B. circulans.

\begin{tabular}{|c|c|c|c|c|c|c|c|}
\hline Treatments & Chl $a$ & Chl $b$ & Caro & $\begin{array}{l}\text { Soluble } \\
\text { Sugars }\end{array}$ & $\begin{array}{l}\text { Soluble } \\
\text { Proteins }\end{array}$ & Proline & MDA \\
\hline Control & $0.34 \pm 0.03^{c}$ & $0.25 \pm 0.03^{c}$ & $0.14 \pm 0.02^{b c}$ & $122.49 \pm 3.68^{b c}$ & $124.92 \pm 3.49^{\mathrm{ab}}$ & $3.54 \pm 0.14^{\mathrm{e}}$ & $41.48 \pm 1.00^{\mathrm{cd}}$ \\
\hline Cu 1 & $0.26 \pm 0.03^{\mathrm{d}}$ & $0.24 \pm 0.03^{c}$ & $0.18 \pm 0.02^{a b c}$ & $113.52 \pm 3.08 \mathrm{de}$ & $97.96 \pm 2.78^{c}$ & $5.86 \pm 0.13^{b}$ & $46.94 \pm 1.70^{b}$ \\
\hline$P p$ & $0.50 \pm 0.02^{\mathrm{a}}$ & $0.43 \pm 0.02^{\mathrm{a}}$ & $0.15 \pm 0.09 a b c$ & $137.78 \pm 2.27^{a}$ & $133.41 \pm 3.30^{\mathrm{a}}$ & $2.77 \pm 0.06^{g}$ & $30.75 \pm 1.66^{g}$ \\
\hline$C u 1+P p$ & $0.42 \pm 0.03^{b}$ & $0.37 \pm 0.03^{b}$ & $0.23 \pm 0.06^{\mathrm{a}}$ & $126.42 \pm 3.12^{b}$ & $120.01 \pm 9.55^{b}$ & $3.70 \pm 0.08$ de & $32.76 \pm 1.00 \mathrm{fg}$ \\
\hline $\mathrm{Cu} 2+P p$ & $0.27 \pm 0.01$ de & $0.23 \pm 0.02^{\mathrm{cd}}$ & $0.19 \pm 0.03^{\mathrm{ab}}$ & $108.87 \pm 4.14^{\mathrm{ef}}$ & $135.18 \pm 5.87^{a}$ & $5.26 \pm 0.10^{c}$ & $39.90 \pm 2.44^{\mathrm{d}}$ \\
\hline $\mathrm{Cu} 2+B c$ & $0.22 \pm 0.03^{\mathrm{e}}$ & $0.19 \pm 0.02^{\mathrm{d}}$ & $0.14 \pm 0.03 \mathrm{abc}$ & $105.86 \pm 6.03^{\mathrm{f}}$ & $127.62 \pm 6.57 \mathrm{ab}$ & $5.65 \pm 0.22^{b}$ & $43.12 \pm 1.11^{c}$ \\
\hline
\end{tabular}

In contrast to the contents of $\mathrm{Chl} a$, the $\mathrm{Chl} b$ was found to be decreased significantly by $\mathrm{Cu}$ 2 concentration versus control and the effect was found to be non-significant at the $\mathrm{Cu} 1 \mathrm{dose}$. The inoculation with $P p$ improved the $\mathrm{Chl} b$ content and its effect was followed by $B c$ under non-stress conditions compared to control plants. In $\mathrm{Cu} 1$ grown plants, the inoculation with $P p$ and $B c$ boosted the $\mathrm{Chl} b$ in comparison to $\mathrm{Cu} 1$ alone plants. $\mathrm{Cu} 2$ plants inoculated with $P p$ and $B c$ respectively also showed a significant increase in $\mathrm{Chl} b$ content compared to $\mathrm{Cu} 2$ alone plants (Table 2).

Caro content remained non-significant up to $\mathrm{Cu} 1$ then a significant decrease was observed in $\mathrm{Cu} 2$ compared to the control. Plants inoculated with $P p$ and $B c$ registered a non-significant increase in Caro content compared to control plants. It was also found that $\mathrm{Cu} 1+P p$ and $\mathrm{Cu} 1+B c$ plants showed a non-significant increase in Caro content against $\mathrm{Cu} 1$ alone plants. However, a significant increase was noticed in $\mathrm{Cu} 2+P p$ treatment compared to $\mathrm{Cu} 2$ treatment alone (Table 2). 


\subsection{Bacterial Inoculation under Graded Levels of Cu Regulates Organic Solutes}

The $\mathrm{Cu} 1$ and 2 treatments resulted in a significant decrease in soluble sugars content compared to controls. The inoculation with $P p$ and $B c$ increased the soluble sugars content under non-stress conditions compared to control plants. Its effect was followed by $\mathrm{Cu} 1+P p$ compared to $\mathrm{Cu} 1$ alone plants. A significant increase was also noted in $\mathrm{Cu} 2+P p$ and $\mathrm{Cu}+B c$ inoculated plants compared to $\mathrm{Cu} 2$ alone plants (Table 2).

The soluble proteins content was diminished under $\mathrm{Cu} 1$, then a non-significant increase in soluble proteins content was noted in $\mathrm{Cu} 2$ plants compared to controls. The inoculation with $P p$ and $B c$ resulted in a non-significant increase in soluble proteins compared to control plants under non-stress conditions. The maize plants grown under $\mathrm{Cu} 1+P p$ and $\mathrm{Cu} 2+B c$ showed a significant increase in the soluble proteins content compared to $\mathrm{Cu} 1$ alone plants. The inoculation with $P p$ and $B c$ in $\mathrm{Cu}$ 2 registered a non-significant increase in soluble proteins content compared to $\mathrm{Cu} 2$ treatment alone (Table 2).

A significant increase was noticed in the proline content of maize seedlings grown under $\mathrm{Cu} 1$ and $\mathrm{Cu} 2$ applications compared to controls. In contrast to soluble sugars and proteins, the $P p$ and $B c$ imposed a decreasing trend in proline compared to the control. The proline content showed a marked decreasing trend with $\mathrm{Pp}$ inoculation in $\mathrm{Cu} 1$ and $\mathrm{Cu} 2$ plants, respectively, in comparison to $\mathrm{Cu} 1$ and $\mathrm{Cu} 2$ alone plants. Our results also showed that a significant decrease in proline content was also recorded when $\mathrm{Cu} 1$ and 2 plants were inoculated with $\mathrm{Bc}$ compared to $\mathrm{Cu} 1$ and $\mathrm{Cu} 2$ plants alone (Table 2).

\subsection{Bacterial Inoculation Diminishes MDA Content under $\mathrm{Cu}$ Stress}

Exposure of maize plants to $\mathrm{Cu} 1$ and 2 doses showed a significant increase in MDA content and this accumulation was maximum in $\mathrm{Cu} 2$ plants over control plants. Inoculation with $P p$ and $B c$ decreased the MDA under non-stress conditions versus the control. The $P p$ and $B c$ inoculation in $\mathrm{Cu} 1$ and $\mathrm{Cu} 2$ plants caused a dramatic decrease in MDA content compared to $\mathrm{Cu} 1$ and 2 alone plants, respectively (Table 2).

\subsection{Bacterial Inoculation Decreases Root and Shoot Cu Content in Maize Plants under Cu Stress}

Maize plants grown under $\mathrm{Cu} 1$ and $\mathrm{Cu} 2$ showed a significant increase in root $\mathrm{Cu}$ content over control plants. Inoculation with $P p$ and $B c$ decreased the root $\mathrm{Cu}$ content compared to control plants in stress-free plants. The inoculation of plants with $P p$ and $B c$ in $\mathrm{Cu} 1$ and $\mathrm{Cu} 2$ induced a significant decrease in $\mathrm{Cu}$ content compared to $\mathrm{Cu} 1$ and 2 alone plants (Figure 1A).

In line with $\mathrm{Cu}$ in root, shoot $\mathrm{Cu}$ content registered a significant increase under $\mathrm{Cu} 1$ and $\mathrm{Cu} 2$ compared to the control plants. The bacterial inoculation with $P p$ caused a significant decrease in the shoot $\mathrm{Cu}$ content but a non-significant increase was noticed in plants inoculated with $B c$ versus the control plants. The $\mathrm{Cu}$ content in shoot decreased significantly in plants inoculated with $P p$ and receiving $\mathrm{Cu} 1$ and $\mathrm{Cu} 2$ respectively versus $\mathrm{Cu} 1$ and $\mathrm{Cu} 2$ alone treatments. Moreover, the $B c$ inoculation treatment in $\mathrm{Cu} 1$ and $\mathrm{Cu} 2$ plants also registered a significant decrease in shoot $\mathrm{Cu}$ content compared to $\mathrm{Cu} 1$ and $\mathrm{Cu} 2$ alone plants (Figure 1B). 

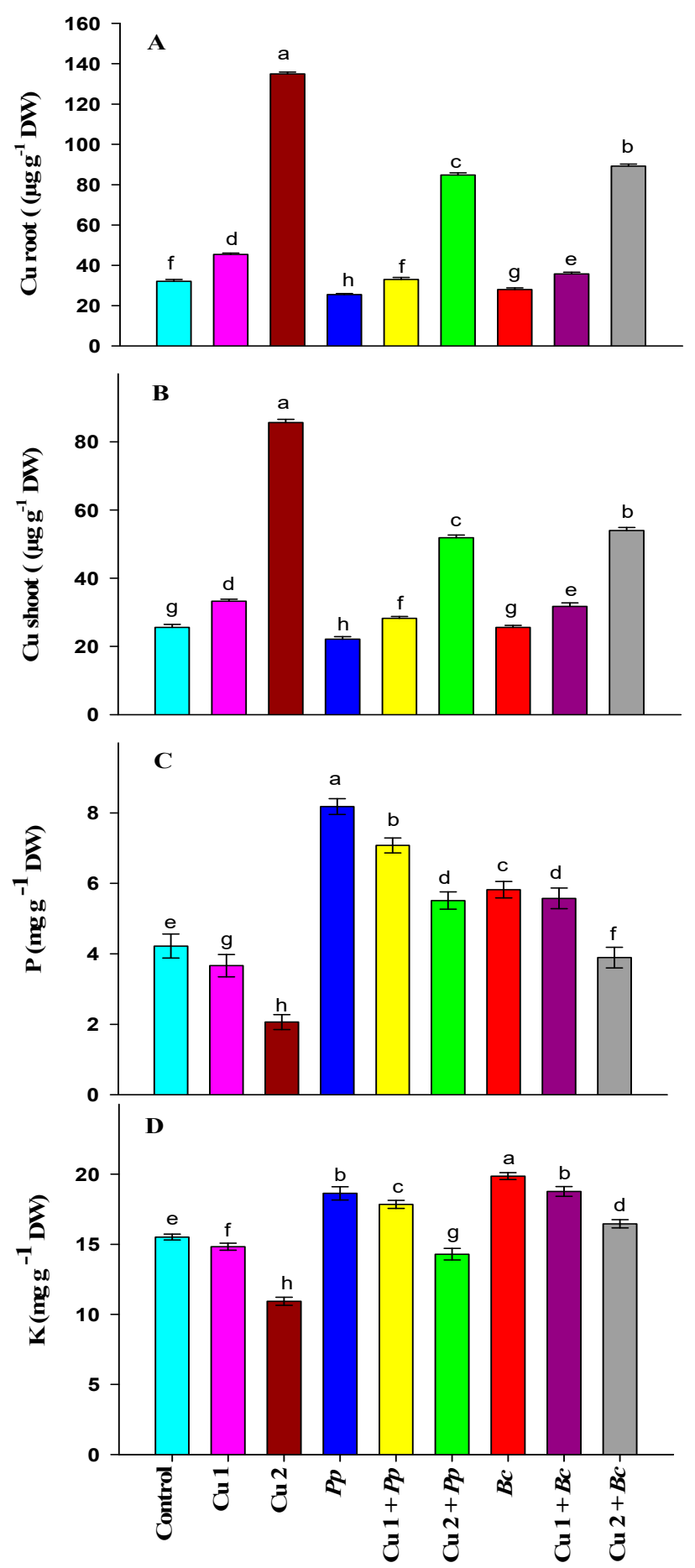

Figure 1. Effects of bacterial inoculation under copper stress on (A) copper in root (B) copper in shoot (C) phosphorous $(\mathrm{P})$ and $(\mathrm{D})$ potassium $(\mathrm{K})$ in maize plants. Bars represent the standard deviation $( \pm \mathrm{SD})$ of the means $(n=3)$. Different letters indicate significant differences among the treatments at $p<0.05$, according to Duncan's multiple range test. The treatments include Control, plants without copper stress and bacterial strains inoculation; $\mathrm{Cu} 1$ : plants exposed to $100 \mu \mathrm{M} \mathrm{CuSO}_{4}$; $\mathrm{Cu} 2$ : plants exposed to $500 \mu \mathrm{M} \mathrm{CuSO}_{4}$; P. polymyxa (Pp) inoculated plants without $\mathrm{CuSO}_{4} ; \mathrm{Cu} 1+P p$ : plants exposed to $100 \mu \mathrm{M} \mathrm{CuSO}_{4}$ and inoculated with P. polymyxa; Cu $2+P p$ : plants exposed to $500 \mu \mathrm{M}$ $\mathrm{CuSO}_{4}$ and inoculated with P. polymyxa; B. circulans $(B c)$ inoculated plants without $\mathrm{CuSO}_{4} ; \mathrm{Cu} 1+B c$ : plants exposed to $100 \mu \mathrm{M} \mathrm{CuSO}_{4}$ and inoculated with $B$. circulans and $\mathrm{Cu} 2+B c$ : plants exposed to $500 \mu \mathrm{M} \mathrm{CuSO}_{4}$ and inoculated with $B$. circulans. 


\subsection{Bacterial Inoculation under $C u$ Stress Increases $P$ and K Contents}

A significant decrement in the P content was noticed under both $\mathrm{Cu} 1$ and $\mathrm{Cu} 2$ doses compared to the control. The inoculation with $P p$ and $B c$ caused a significant increment in $P$ versus the control treatment. A significant increase in P content was observed in $P p+\mathrm{Cu} 1$ and $P p+\mathrm{Cu} 2$ treatments compared to the respective $\mathrm{Cu}$ treatments. The treatments: $B c+\mathrm{Cu} 1$ and $B c+\mathrm{Cu} 2$ registered a significant increase in $\mathrm{P}$ content compared to $\mathrm{Cu} 1$ and $\mathrm{Cu} 2$ treatments (Figure 1C).

In line with $\mathrm{P}, \mathrm{K}$ content also exhibited a significant decrease under $\mathrm{Cu} 1$ and $\mathrm{Cu} 2$ doses compared to the control. The $\mathrm{Cu} 2$ then $\mathrm{Cu} 1$ grown plants showed a maximum and more significant decrease versus control plants. The bacterial inoculation with $P p$ and $B c$ increased the $\mathrm{K}$ content over the control. In this case, the $\mathrm{K}$ content was found to be highest in plants inoculated with $B c$. In $\mathrm{Cu} 1$ and $\mathrm{Cu} 2$ plants, inoculation with $P p$, respectively, increased $\mathrm{K}$ content versus $\mathrm{Cu} 1$ and $\mathrm{Cu} 2$ alone treatments. The inoculation treatments with $\mathrm{Bc}$ in $\mathrm{Cu} 1$ and $\mathrm{Cu} 2$ plants also registered a significant increase in $\mathrm{K}$ content compared to $\mathrm{Cu} 1$ and $\mathrm{Cu} 2$ alone treatments (Figure 1D).

\subsection{Bacterial Inoculation Modulates the Antioxidant Enzymes of Maize Plants under Cu Stress}

The $\mathrm{Cu} 1$ and $\mathrm{Cu} 2$ doses decreased the activity of CAT significantly compared to controls. The $P p$ and $B c$ inoculation resulted in a marked increment in the activity of CAT compared to control plants. In $\mathrm{Cu} 1+P p$ and $\mathrm{Cu} 2+P p$ plants, the CAT activity was increased over $\mathrm{Cu} 1$ and $\mathrm{Cu} 2$ alone plants. Additionally, $B c$ inoculation in $\mathrm{Cu} 1$ and 2 plants had an additive and significant effect on CAT activity in comparison to plants treated with $\mathrm{Cu} 1$ and 2 alone (Figure 2A).

Maize plants grown with $\mathrm{Cu} 1$ and $\mathrm{Cu} 2$ showed a significant increase in POD activity compared to control plants. A significant increase was also noticed in POD activity when plants were inoculated with $P p$ and $B c$ versus the control plants. A significant increase in the POD activity by $P p$ inoculation under $\mathrm{Cu} 1$ and $\mathrm{Cu} 2$ stress conditions was noticed compared to $\mathrm{Cu} 1$ and $\mathrm{Cu} 2$ alone plants. The POD activity was also incremented significantly with $B c$ inoculation in presence of $\mathrm{Cu} 1$ and $\mathrm{Cu} 2$ compared to $\mathrm{Cu} 1$ and $\mathrm{Cu} 2$ alone plants (Figure 2B).

The $\mathrm{Cu} 1$ dose caused a non-significant in the activity of APX but $\mathrm{Cu} 2$ dose induced a significant increase with respect to control plants. The inoculation with $P p$ and $B c$ in stress-free plants increased APX activity significantly compared to control plants. Treatment of maize plants with $\mathrm{Cu} 1$ and 2 and receiving either $B c$ and/or $P p$ inoculation registered a significant increase in APX activity compared to $\mathrm{Cu} 1$ and 2 alone treated plants (Figure 2C).

\subsection{Understanding Interactions between Bacterial Inoculation, Various Cu Doses and Variables Studied through PCA Approach}

A PCA (loading and score plot) was constructed to study the interaction between various variables and doses of $\mathrm{Cu}$ to assess the maximum variability of data and to bacterial inoculation treatments. The loading plot shown in Figure 3A of various variables advocated that growth, photosynthetic pigments, organic solutes and antioxidants enzymes were positively correlated with each other and negatively with MDA, proline and $\mathrm{Cu}$ root and shoot contents. The score plot (Figure 3B) represented the authenticated grouping of various treatments (bacterial inoculation and $\mathrm{Cu}$ doses). The control treatment along with $B c$ and $P p$ inoculation treatments was adjudged as the best value giving treatments. Its effect was followed by that of $\mathrm{Cu} 1+B c$ and $\mathrm{Cu} 1+P p$. This shows the alleviating effect of $P p$ and $B c$ inoculation in the presence of $\mathrm{Cu}$ doses. The $\mathrm{Cu}$ doses in the absence of bacterial inoculation impose severe negative growth restrictions in maize plants as both these treatments were clustered on the upper left-hand side of the score plot. The highest dose of $\mathrm{Cu}(\mathrm{Cu} 2)$ along with $P p$ or $B c$ inoculation were grouped together in the lower two rectangles of the score plot. There was less alleviation in the presence of the highest dose of $\mathrm{Cu}$ with bacterial inoculation and this was confirmed by score plot as these treatments were grouped together in a negative component (Figure 3B). 

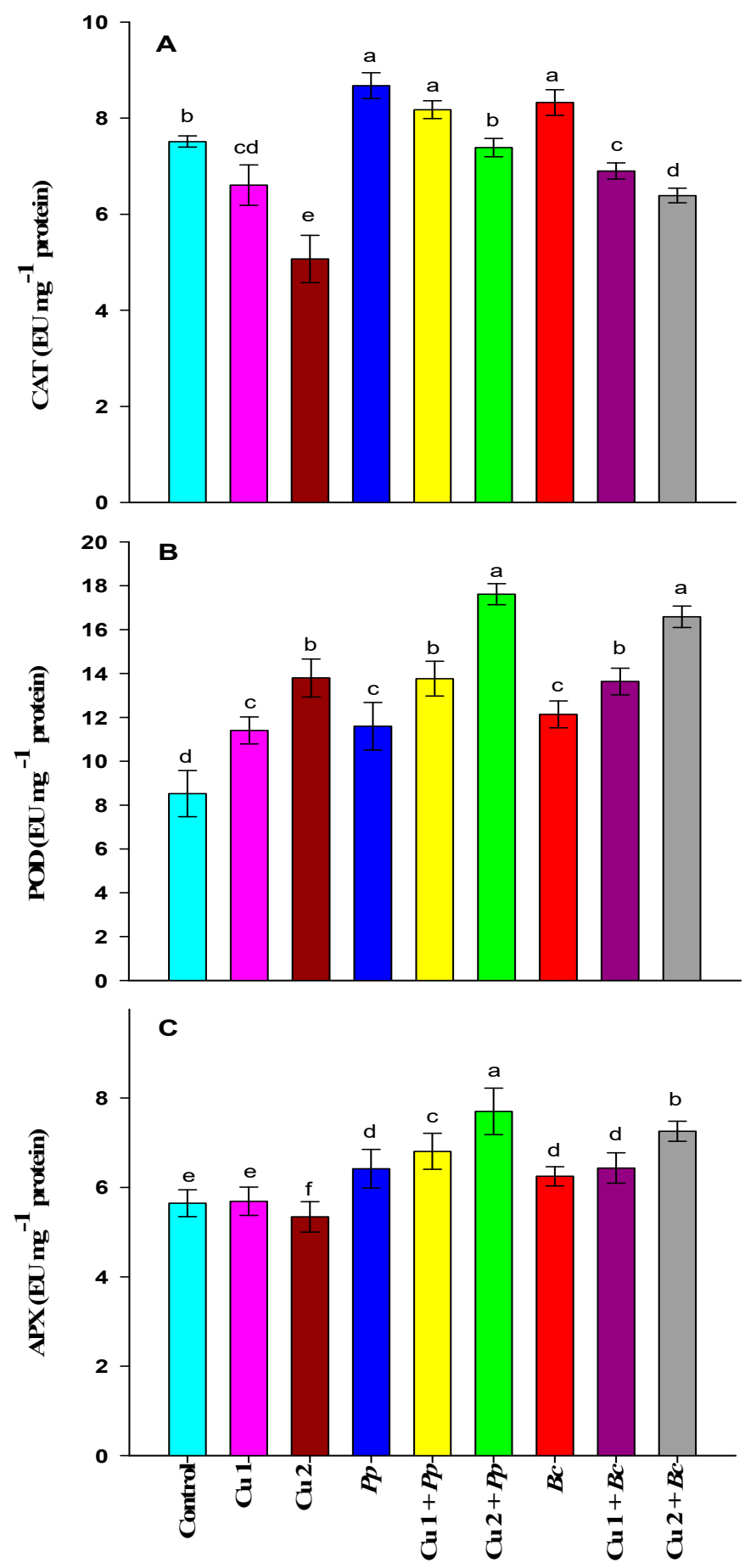

Figure 2. Effects of bacterial inoculation under copper stress on the activities (A) catalase (CAT), (B) peroxidase (POD), and (C) ascorbate peroxidase (APX) in leaves of maize plants. Bars represent the standard deviation $( \pm \mathrm{SD})$ of the means $(n=3)$. Different letters indicate significant differences among the treatments at $p<0.05$, according to Duncan's multiple range test. The treatments include Control, plants without copper stress and bacterial strains inoculation; $\mathrm{Cu} 1$ : plants exposed to $100 \mu \mathrm{M}$ $\mathrm{CuSO}_{4} ; \mathrm{Cu} 2$ : plants exposed to $500 \mu \mathrm{M} \mathrm{CuSO}_{4} ;$ P. polymyxa (Pp) inoculated plants without $\mathrm{CuSO}_{4} ; \mathrm{Cu}$ $1+P p$ : plants exposed to $100 \mu \mathrm{M} \mathrm{CuSO}_{4}$ and inoculated with $P$. polymyxa; $\mathrm{Cu} 2+P p$ : plants exposed to $500 \mu \mathrm{M} \mathrm{CuSO}_{4}$ and inoculated with P. polymyxa; B. circulans (Bc) inoculated plants without $\mathrm{CuSO}_{4}$; $\mathrm{Cu} 1+B c$ : plants exposed to $100 \mu \mathrm{M} \mathrm{CuSO}_{4}$ and inoculated with $B$. circulans and $\mathrm{Cu} 2+B c$ : plants exposed to $500 \mathrm{\mu M} \mathrm{CuSO}_{4}$ and inoculated with B. circulans. 

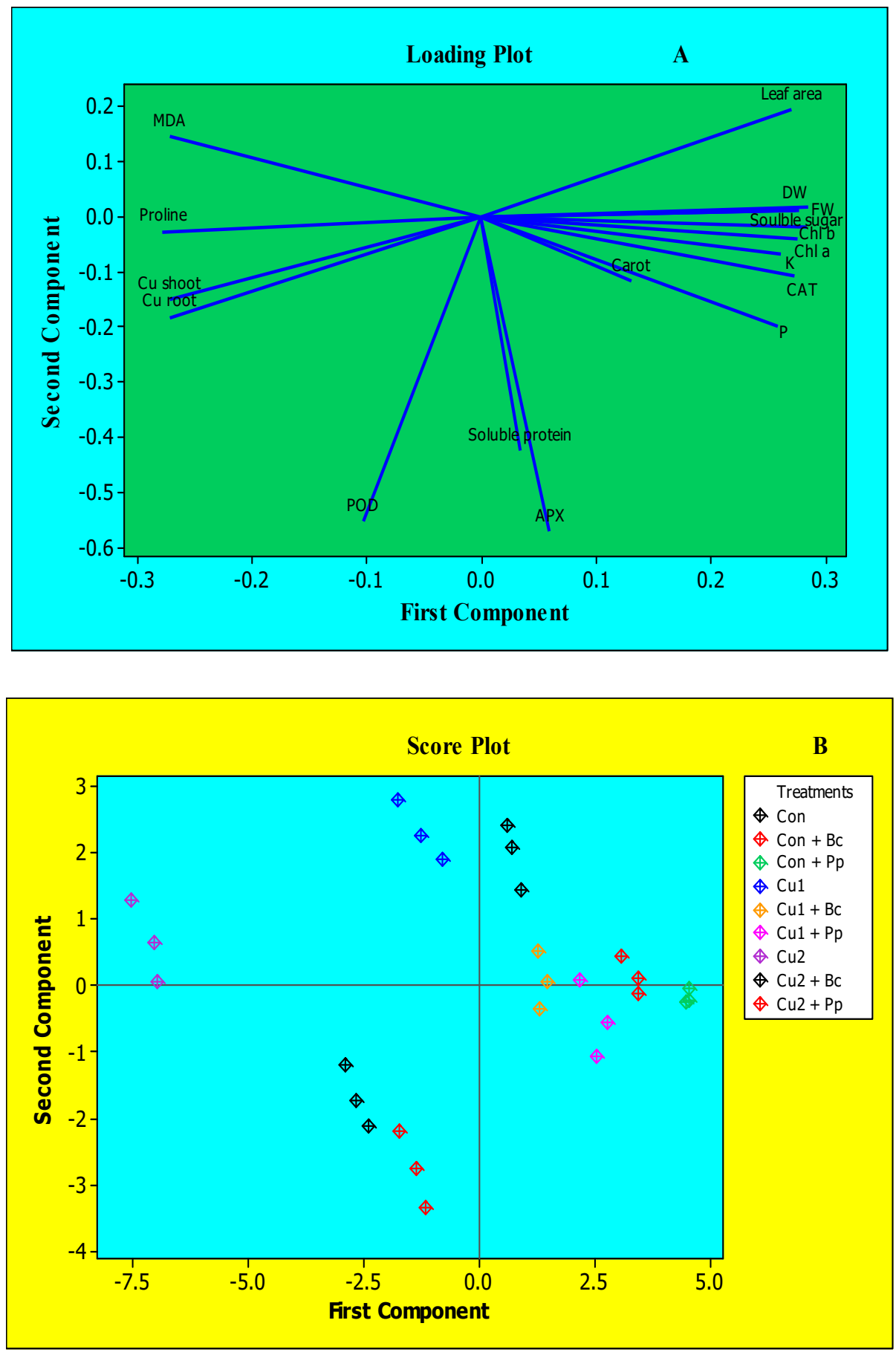

Figure 3. Principal component analysis (PCA) to understand parameter and treatment variability in maize plants. (A) The parameters included FW (fresh weight) DW (dry weight), leaf area, Chl $a$ (chlorophyll $a$ ), Chl $b$ (chlorophyll $b$ ), Carot (carotenoids), soluble sugars, soluble protein, proline, MDA (malondialdehyde), CAT (catalase), APX (ascorbate peroxidase), POD (peroxidase), P (phosphorous) and $\mathrm{K}$ (potassium). (B) The treatment triangles in different colors include Control, plants without copper stress and bacterial strains inoculation; $\mathrm{Cu} 1$ : plants exposed to $100 \mu \mathrm{M} \mathrm{CuSO}_{4} ; \mathrm{Cu} 2$ : plants exposed to $500 \mu \mathrm{M} \mathrm{CuSO}_{4} ;$ P. polymyxa (Pp) inoculated plants without $\mathrm{CuSO}_{4} ; \mathrm{Cu} 1+P p$ : plants exposed to $100 \mu \mathrm{M} \mathrm{CuSO}_{4}$ and inoculated with P. polymyxa; Cu $2+P p$ : plants exposed to $500 \mu \mathrm{M}$ $\mathrm{CuSO}_{4}$ and inoculated with P. polymyxa; B. circulans $(B c)$ inoculated plants without $\mathrm{CuSO}_{4} ; \mathrm{Cu} 1+B c$ : plants exposed to $100 \mu \mathrm{M} \mathrm{CuSO}_{4}$ and inoculated with $B$. circulans and $\mathrm{Cu} 2+B c$ : plants exposed to $500 \mu \mathrm{M} \mathrm{CuSO}_{4}$ and inoculated with B. circulans. 


\section{Discussion}

In the present communication, an appraisal has been made to unravel various physio-biochemical mechanisms induced by PGPRs under $\mathrm{Cu}$ stress in maize plants. It is well established that the $\mathrm{Cu}$ doses induced growth inhibition reflected in the form of fresh and dry weight and leaf area of maize plants (Table 1). It may be attributed to excess $\mathrm{Cu}$ phytotoxicity and interruptions in mineral nutrients which resulted in the inhibition of cell division and cell elongation [61], respiration and photosynthesis in plants [62]. Additionally, the reduction in growth traits under Cu-treated maize plants in the present study may also be ascribed to the higher acquisition of excess $\mathrm{Cu}$ ions resulting in the reduction of the mineral nutrient contents (Figure 1C,D) which resulted in an inhibition of the functioning of important $\mathrm{Cu}$-containing metalloproteins required to achieve optimum cell growth and metabolism [63]. In contrast, both PGPRs tested to alleviate the $\mathrm{Cu}$ phytotoxicity proved effective and increased the aforementioned growth characteristics. The increment in PGPR mediated growth traits could be due to the secretion of various plant hormones in the rhizosphere as well as a tight regulation in the endogenous levels of these plant hormones [64]. These plant hormones are known to maintain cell division and cell elongation processes to a great extent [65], thereby increasing fresh and dry weight as well as leaf area after inoculation with P. polymyxa and B. circulans in this study. A similar improvement in growth traits by Bacillus strains under $\mathrm{Mn}$ in Broussonetia papyrifera conforms to our present results [66]. A similar increase in growth traits through PGPR inoculation was also recorded in maize plants [67-71].

In the present report, the application of $\mathrm{Cu}$ especially $\mathrm{Cu} 2$ also decreased $\mathrm{Chl} a, b$ and Caro contents (Table 2) and this decrement is due to the reaction of $\mathrm{Cu}$ with thiol groups of the enzymes like $\delta$-aminolevulinic dehydrogenase and protochlorophyllide reductase complex [72]. Cu induced decreased photosynthetic pigments could also be attributed to impairment in chloroplast structure and composition of thylakoid membrane, photophosphorylation of PS I and PS II, increased photoinhibition and reduction in the photosynthetic electron transport chain [73,74]. A similar decrease in these pigments has been reported in jute [75,76], cilantro [77], lentil [78], spearmint [79] and maize [41] plants. The results of this study showed that in each treatment group of inoculation with P. polymyxa and B. Circulans increased the photosynthetic pigments under optimal and $\mathrm{Cu}$ stress conditions (Table 1). It indicated that the two tested PGPR improved the absorption and utilization of plant minerals and which in turn promoted the biosynthesis of proteins and chlorophyll. The two strains accelerated the absorption and transport of minerals via carriers under $\mathrm{Cu}$ stress, which in turn could maintain the synthesis of pigments $[66,80,81]$ even under $\mathrm{Cu}$ stress. These results are in harmony with the results of Kamran et al. [82] and Awan et al. [36].

In this study, Cu doses along with PGPR inoculation showed the highest content of osmolytes (soluble sugars and soluble proteins) in the maize plants (Table 2). Increased osmolytes content under $\mathrm{Cu}$ stress conditions has aided plants to maintain optimal water balance by regulating turgor and osmotic pressure $[10,83,84]$. In the present work, elevated content of osmolytes under $\mathrm{Cu}$ doses under PGPR inoculation could have preserved sustained redox homeostasis which resulted in optimal plant metabolism. A similar increase in osmolytes content under metal stress by PGPR inoculation was reported in maize [36,85], sunflower [26], rape seedlings [86], potato [24], tomato [87], curtis [88] and lentil [89] plants. Interestingly, the inoculation with $P p$ and $B c$ diminished the accumulation of proline content in the $\mathrm{Cu}$ stressed seedlings (Figure $1 \mathrm{~A}, \mathrm{~B}$ ), which is linked with enhanced growth of maize plants under $\mathrm{Cu}$ stress (Table 1). This finding proposed that the inoculation with $P p$ and $B c$ could enable safeguarding of cells by maintaining the accumulation of proline to an optimal level, and PGPR inoculation possibly utilized other osmolytes for $\mathrm{Cu}$ stress alleviation, in which the high level of proline accumulation was not needed.

Plants are equipped with antioxidant defense enzyme activities which include SOD, CAT, POD and APX to manage the metal-induced oxidative damage and lessen the accumulation of various ROS. In the present work, the increase in root and shoot $\mathrm{Cu}$ content (Figure 1A,B) and MDA level (Table 2) indicates the dose-dependent extent of $\mathrm{Cu}$-induced oxidative damage which negatively 
affects the membrane's integrity. In contrast, the antioxidant enzymes (CAT, POD and APX) play the dominant role in alleviating $\mathrm{Cu}$-induced oxidative damage. The activities of antioxidant enzymes, such as CAT, POD, and APX (Figure 2) were increased in maize plants inoculated with PGPR. Notably, the detrimental impact of $\mathrm{Cu}$ stress was reduced by the inoculation of PGPR, which significantly upsurges these activities. On one hand, it was observed that PGPR increased antioxidant activities and, on the other decreased root and shoot $\mathrm{Cu}$ (Figure 1A,B) and MDA (Table 2) content in maize plants grown under $\mathrm{Cu}$ conditions. Khanna et al. [90] stated that PGPR application lowered metal uptake by reducing the expression of metal transporter genes in tomato plants. The present investigation showed that PGPR boosted maize tolerance to $\mathrm{Cu}$ stress by minimizing $\mathrm{Cu}$ accumulation and translocation from root to shoot, thus protecting maize against $\mathrm{Cu}$ toxicity and enhancing maize growth. Our findings are also supported by Fatnassi et al. [91], who stated that the increased antioxidant enzymes activity inoculated with the PGPRs reduced Cu stress in Vicia faba plants. In yet another study, Ju et al. [92] reported the impact of co-inoculation of PGPR and rhizobium on the biochemical responses of alfalfa plants under $\mathrm{Cu}$ stress conditions and found that inoculating plants decreased MDA content on one hand and increased antioxidant activities on the other, thus further supporting our present findings.

Our results determined that the application of $\mathrm{Cu}$ to maize plants decreased $\mathrm{P}$ and $\mathrm{K}$ levels (Figure 1C,D). Cu is known to reduce the uptake and aggregation of plant nutrients due to direct competition with these nutrients [93]. A similar $\mathrm{Cu}$ mediated decrease in mineral nutrients has been reported in maize $[42,94,95]$, which is in line with our current findings. On the other hand, we observed that $P$. polymyxa and B. circulans inoculation significantly increased these contents under $\mathrm{Cu}$ doses. It has been reported that $P$. polymyxa stimulates the plant's nutrient acquisition machinery by transcriptionally activating the nutrient-deficiency-induced transcription factors in addition to secreting auxins and cytokinins [96-98]. The increased availability of nutrient uptake by P. polymyxa inoculation in the presence of $\mathrm{Cu}$ doses could have increased nutrient transport in maize plants which resulted in an increase in $\mathrm{P}$ and $\mathrm{K}$ contents. Nevertheless, Bacillus strains are also known to solubilize soil $\mathrm{P}$ pools, thus increasing its uptake and translocation to plants [99]. A similar increase in plant mineral nutrients by the inoculation of Bacillus strains has been recorded in maize plants $[69,100,101]$, which are in support of our present findings.

PCA has further confirmed a strong correlation between the inoculation of PGPR strains and plant physio-biochemical attributes under $\mathrm{Cu}$ stress conditions. For the determination of approximate association of various biochemical and morpho-physiological traits and different treatments, loading and score plots were constructed (Figure 3A,B). PCA results validated the cluster analysis of different treatments. For example, Control (Con), $C o n+B c$ and $C o n+P p$ treatments were grouped together, and these three treatments were associated with LA, chlorophyll $a$ and $b, \mathrm{FW}, \mathrm{DW}$, soluble sugar. This means that these two strains of bacteria treatment increased these traits in a significant manner. The low dose of $\mathrm{Cu}$ treatments along with PGPR inoculation like $\mathrm{Cu} 1+B c$ and $\mathrm{Cu} 1+P p$ were also grouped together. These two treatments represented the maximum alleviation effect under low $\mathrm{Cu}$ dose. The two $\mathrm{Cu}$ $(\mathrm{Cu} 1$ and $\mathrm{Cu} 2)$ doses without PGPR inoculation were found to be grouped together. These treatments represented the toxic effect of $\mathrm{Cu}$ doses on various biochemical and morpho-physiological traits on maize plants. The treatments $\mathrm{Cu} 2+B c$ and $\mathrm{Cu} 2+P p$ depicted the minimum alleviation effect by PGPR inoculation under high $\mathrm{Cu}$ doses and were both grouped together.

\section{Conclusions}

The present work on maize plants showed that $\mathrm{Cu}$ doses increased root and shoot $\mathrm{Cu}$ content, proline, MDA content, POD activity and decreased most of the biochemical and morpho-physiological characters in a dose-dependent manner. The inoculation with PGPR strains has shown a significant decrease in stress caused by the $\mathrm{Cu}$ doses on all studied plant attributes by improving pigments and mineral nutrients, reducing the accumulation of $\mathrm{Cu}$ in root and shoot, and augmentation the ROS scavenging system via an elevated antioxidant defense system. The antioxidant defense system and 
osmolytes play a central role in the alleviation of $\mathrm{Cu}$ toxicity of maize plants which in turn improved maize growth.

Author Contributions: Conceptualization, A.A.H.A.L.; methodology, A.A.H.A.L., M.F.A.A., A.-B.A.-E.A.-B. and W.S., software, A.Z.; validation, A.A.H.A.L., M.F.A.A. and A.Z.; formal analysis, A.A.H.A.L. and M.F.A.A.; investigation, M.F.A.A., A.-B.A.-E.A.-B. and W.S.; resources, A.A.H.A.L., M.F.A.A., W.S. A.-B.A.-E.A.-B. and A.Z.; data curation, A.A.H.A.L., A.Z., and M.F.A.A; writing-original draft preparation, A.Z; writing-review and editing, A.A.H.A.L. and A.Z., visualization, A.A.H.A.L; supervision, A.A.H.A.L. project administration, A.A.H.A.L.; funding acquisition, A.A.H.A.L and. All authors have read and agreed to the published version of the manuscript.

Funding: This research was funded by Taif University Researchers Supporting Project number (TURSP-2020/72), Taif University, Taif, Saudi Arabia.

Acknowledgments: Abbu Zaid is thankful to Aligarh Muslim University, Aligarh and New Delhi (India) for providing a seat to work as well as financial assistance.

Conflicts of Interest: The authors declare no conflict of interest.

\section{References}

1. Lin, Y.F.; Aarts, G.M. The molecular mechanism of zinc and cadmium stress response in plants. Cell Mol. Life Sci. 2012, 69, 3187-3206. [CrossRef] [PubMed]

2. Wani, W.; Masoodi, K.Z.; Zaid, A.; Wani, S.H.; Shah, F.; Meena, V.S.; Mosa, K.A. Engineering plants for heavy metal stress tolerance. RendRendiconti Lincei. Scienze Fisiche e Naturali 2018, 29, 709-723. [CrossRef]

3. Ali, S.; Rizwan, M.; Zaid, A.; Arif, M.S.; Yasmeen, T.; Hussain, A.; Abbasi, G.H. 5-Aminolevulinic acid-induced heavy metal stress tolerance and underlying mechanisms in plants. J. Plant Growth Regul. 2018, 37, 1423-1436. [CrossRef]

4. Sharma, A.; Sidhu, G.P.S.; Araniti, F.; Bali, A.S.; Shahzad, B.; Tripathi, D.K.; Landi, M. The role of salicylic acid in plants exposed to heavy metals. Molecules 2020, 25, 540. [CrossRef] [PubMed]

5. Shivaraj, S.M.; Vats, S.; Bhat, J.A.; Dhakte, P.; Goyal, V.; Khatri, P.; Sharma, T.R. Nitric oxide and hydrogen sulfide crosstalk during heavy metal stress in plants. Physiol. Plant 2020, 168, 437-455. [CrossRef]

6. Marschner, P. Marschner's Mineral Nutrition of Higher Plants, 3rd ed.; Academic Press: Cambridge, MA, USA; Elsevier Ltd.: London, UK, 2013.

7. Pichhode, M.; Nikhil, K. Effect of copper mining dust on the soil and vegetation in India: A critical review. Int. J. Mod. Sci. Eng. Technol. 2015, 2, 73-76.

8. Nazir, F.; Hussain, A.; Fariduddin, Q. Hydrogen peroxide modulate photosynthesis and antioxidant systems in tomato (Solanum lycopersicum L.) plants under copper stress. Chemosphere 2019, 230, 544-558. [CrossRef]

9. Ameh, T.; Sayes, C.M. The potential exposure and hazards of copper nanoparticles: A review. Environ. Toxicol. Pharmacol. 2019, 71, 103220. [CrossRef]

10. Shabbir, Z.; Sardar, A.; Shabbir, A.; Abbas, G.; Shamshad, S.; Khalid, S.; Shahid, M. Copper uptake, essentiality, toxicity, detoxification and risk assessment in soil-plant environment. Chemosphere 2020, 127436. [CrossRef]

11. Huang, C.H.; Kuo, W.; Weiss, C.; Jinn, T.L. Copper chaperone-dependent and independent activation of three copper-zinc superoxide dismutase homologs localized in different cellular compartments in Arabidopsis. Plant Physiol. 2012, 158, 737-746. [CrossRef]

12. Sánchez-Pardo, B.; Fernández-Pascual, M.; Zornoza, P. Copper microlocalisation and changes in leaf morphology, chloroplast ultrastructure and antioxidative response in white lupin and soybean grown in copper excess. J. Plant. Res. 2014, 127, 119-129. [CrossRef] [PubMed]

13. Aghajanzadeh, T.A.; Prajapati, D.H.; Burow, M. Copper toxicity affects indolic glucosinolates and gene expression of key enzymes for their biosynthesis in Chinese cabbage. Arc. Agron. Soil Sci. 2019, 66, 1288-1301. [CrossRef]

14. Rather, B.A.; Masood, A.; Sehar, Z.; Majid, A.; Anjum, N.A.; Khan, N.A. Mechanisms and role of nitric oxide in phytotoxicity-mitigation of copper. Front. Plant Sci. 2020, 11, 675.

15. Huang, W.L.; Wu, F.L.; Huang, H.Y.; Huang, W.T.; Deng, C.L.; Yang, L.T.; Chen, L.S. Excess Copper-Induced Alterations of Protein Profiles and Related Physiological Parameters in Citrus Leaves. Plants 2020, 9, 291. [CrossRef] 
16. Jain, A.; Chakraborty, J.; Das, S. Underlying mechanism of plant-microbe crosstalk in shaping microbial ecology of the rhizosphere. Acta Physiol. Plant 2020, 42, 1-13. [CrossRef]

17. Choudhary, D.K.; Varma, A.; Tuteja, N. (Eds.) Plant-Microbe Interaction: An Approach to Sustainable Agriculture; Springer: Singapore, 2016.

18. Ashraf, M.A.; Hussain, I.; Rasheed, R.; Iqbal, M.; Riaz, M.; Arif, M.S. Advances in microbe-assisted reclamation of heavy metal contaminated soils over the last decade: A review. J. Environ. Manag. 2017, 198, 132-143. [CrossRef]

19. Jacoby, R.; Peukert, M.; Succurro, A.; Koprivova, A.; Kopriva, S. The role of soil microorganisms in plant mineral nutrition—current knowledge and future directions. Front. Plant Sci. 2017, 8, 1617. [CrossRef] [PubMed]

20. Khan, N.; Bano, A.; Ali, S.; Babar, M.A. Crosstalk amongst phytohormones from planta and PGPR under biotic and abiotic stresses. Plant Growth Regul. 2020, 90, 189-203. [CrossRef]

21. Silambarasan, S.; Logeswari, P.; Cornejo, P.; Abraham, J.; Valentine, A. Simultaneous mitigation of aluminum, salinity and drought stress in Lactuca sativa growth via formulated plant growth promoting Rhodotorulamucilaginosa CAM4. Ecotoxicol. Environ. Saf. 2019, 180, 63-72. [CrossRef]

22. Bharti, N.; Barnawal, D.; Awasthi, A.; Yadav, A.; Kalra, A. Plant growth promoting rhizobacteria alleviate salinity induced negative effects on growth, oil content and physiological status in Mentha arvensis. Acta Physiol. Plant. 2014, 36, 45-60. [CrossRef]

23. Ilangumaran, G.; Smith, D.L. Plant growth promoting rhizobacteria in amelioration of salinity stress: A systems biology perspective. Front. Plant Sci. 2017, 8, 1768. [CrossRef] [PubMed]

24. Gururani, M.A.; Upadhyaya, C.P.; Baskar, V.; Venkatesh, J.; Nookaraju, A.; Park, S.W. Plant growth-promoting rhizobacteria enhance abiotic stress tolerance in Solanum tuberosum through inducing changes in the expression of ROS-scavenging enzymes and improved photosynthetic performance. J. Plant Growth Regul. 2013, 32, 245-258. [CrossRef]

25. Bakhshandeh, E.; Gholamhosseini, M.; Yaghoubian, Y.; Pirdashti, H. Plant growth promoting microorganisms can improve germination, seedling growth and potassium uptake of soybean under drought and salt stress. Plant Growth Regul. 2020, 90, 123-136. [CrossRef]

26. Qadir, M.; Hussain, A.; Hamayun, M.; Shah, M.; Iqbal, A.; Murad, W. Phytohormones producing rhizobacterium alleviates chromium toxicity in Helianthus annuus L. by reducing chromate uptake and strengthening antioxidant system. Chemosphere 2020, 258, 127386. [CrossRef]

27. Asghari, B.; Khademian, R.; Sedaghati, B. Plant growth promoting rhizobacteria (PGPR) confer drought resistance and stimulate biosynthesis of secondary metabolites in pennyroyal (Mentha pulegium L.) under water shortage condition. Sci. Horticul. 2020, 263, 109132. [CrossRef]

28. Vishwakarma, K.; Singh, V.P.; Prasad, S.M.; Chauhan, D.K.; Tripathi, D.K.; Sharma, S. Silicon and plant growth promoting rhizobacteria differentially regulate AgNP-induced toxicity in Brassica juncea: Implication of nitric oxide. J. Hazard. Mater. 2020, 390, 121806. [CrossRef]

29. Ansari, M.; Shekari, F.; Mohammadi, M.H.; Juhos, K.; Végvári, G.; Biró, B. Salt-tolerant plant growth-promoting bacteria enhanced salinity tolerance of salt-tolerant alfalfa (Medicago sativa L.) cultivars at high salinity. Acta Physiol. Plant. 2019, 41, 195. [CrossRef]

30. Li, H.Q.; Jiang, X.W. Inoculation with plant growth-promoting bacteria (PGPB) improves salt tolerance of maize seedling. Russ. J. Plant Physiol. 2017, 64, 235-241.

31. Rojas-Tapias, D.; Moreno-Galván, A.; Pardo-Díaz, S.; Obando, M.; Rivera, D.; Bonilla, R. Effect of inoculation with plant growth-promoting bacteria (PGPB) on amelioration of saline stress in maize (Zea mays). Appl. Soil Ecol. 2012, 61, 264-272. [CrossRef]

32. Zerrouk, I.Z.; Rahmoune, B.; Khelifi, L.; Mounir, K.; Baluska, F.; Ludwig-Müller, J. Algerian Sahara PGPR confers maize root tolerance to salt and aluminum toxicity via ACC deaminase and IAA. Acta Physiol. Plant 2019, 41, 91. [CrossRef]

33. Malekzadeh, E.; Alikhani, H.A.; Savaghebi-Firoozabadi, G.R.; Zarei, M. Bioremediation of cadmium-contaminated soil through cultivation of maize inoculated with plant growth-promoting rhizobacteria. Biorem. J. 2012, 16, 204-211. [CrossRef]

34. Chukwuneme, C.F.; Babalola, O.O.; Kutu, F.R.; Ojuederie, O.B. Characterization of actinomycetes isolates for plant growth promoting traits and their effects on drought tolerance in maize. J. Plant Interac. 2020, 15, 93-105. [CrossRef] 
35. Beirinckx, S.; Viaene, T.; Haegeman, A.; Debode, J.; Amery, F.; Vandenabeele, S.; De Tender, C. Tapping into the maize root microbiome to identify bacteria that promote growth under chilling conditions. Microbiome 2020, 8, 1-13. [CrossRef]

36. Awan, S.A.; Ilyas, N.; Khan, I.; Raza, M.A.; Rehman, A.; Rizwan, M.; Rastogi, A.; Tariq, R.; Brestic, M. Bacillus siamensis Reduces Cadmium Accumulation and Improves Growth and Antioxidant Defense System in Two Wheat (Triticum aestivum L.) Varieties. Plants 2020, 9, 878.

37. Rizwan, M.; Ali, S.; Qayyum, M.F.; Ok, Y.S.; Zia-ur-Rehman, M.; Abbas, Z.; Hannan, F. Use of maize (Zea mays L.) for phytomanagement of Cd-contaminated soils: A critical review. Environ. Geochem. Health 2017, 39, 259-277. [CrossRef]

38. Vatehová, Z.; Malovíková, A.; Kollárová, K.; Kučerová, D.; Lišková, D. Impact of cadmium stress on two maize hybrids. Plant Physiol. Biochem. 2016, 108, 90-98. [CrossRef]

39. Matayoshi, C.L.; Pena, L.B.; Arbona, V.; Gómez-Cadenas, A.; Gallego, S.M. Early responses of maize seedlings to $\mathrm{Cu}$ stress include sharp decreases in gibberellins and jasmonates in the root apex. Protoplasma 2020, 257, 1243-1256. [CrossRef] [PubMed]

40. Moravcová, Š.; Tůma, J.; Dučaiová, Z.K.; Waligórski, P.; Kula, M.; Saja, D.; Libik-Konieczny, M. Influence of salicylic acid pretreatment on seeds germination and some defence mechanisms of Zea mays plants under copper stress. Plant Physiol. Biochem. 2018, 122, 19-30. [CrossRef] [PubMed]

41. Mocquot, B.; Vangronsveld, J.; Clijsters, H.; Mench, M. Copper toxicity in young maize (Zea mays L.) plants: Effects on growth, mineral and chlorophyll contents, and enzyme activities. Plant Soil 1996, 182, 287-300. [CrossRef]

42. Ouzounidou, G.; Čiamporová, M.; Moustakas, M.; Karataglis, S. Responses of maize (Zea mays L.) plants to copper stress-I. Growth, mineral content and ultrastructure of roots. Environ. Exp. Bot. 1995, 35, 167-176. [CrossRef]

43. Doncheva, S. Copper-induced alterations in structure and proliferation of maize root meristem cells. J. Plant Physiol. 1998, 153, 482-487. [CrossRef]

44. Abo-Baker, A.A. Effect of Some Soil Properties on Efficiency and Activity of Phosphate Dissolving Bacteria in Some Soils of Aswan Area. (Lake Nasser Area). Master's Thesis, Faculty of Agriculture, Al-Azhar University, Cairo, Egypt, 1996.

45. Abo-Baker, A.A. Studies on Mixed and Single Microbial Inoculations of Cultivated Plants for Improvement of Growth and Yield. Ph.D. Thesis, Faculty of Agriculture, Assiut University, Assiut, Egypt, 2003.

46. Abdel-Latef, S.A. Evaluation of Some Medicinal and Aromatic Crops Production Using Different Agricultural Techniques in Reclaimed Soils. Master's Thesis, Faculty of Agriculture, Sohag University, Sohag, Egypt, 2013.

47. Abdel-Latef, S.A.; Hassanein, A. Growth, yield and seed quality of caraway under chemical, organic or biological production in new reclaimed soil of upper Egypt. J. Hort. Sci. Ornamen. Plants 2016, 8, 66-73.

48. Abdel Latef AAH, A.; Alhmad, M.F.A.; Kordrostami, M.; Abo-Baker, A.B.A.E.; Zakir, A. Inoculation with Azospirillum lipoferum or Azotobacter chroococcum reinforces maize growth by improving physiological activities under saline conditions. J. Plant Growth Regul. 2020, 39, 1293-1306. [CrossRef]

49. Lichtenthaler, H.; Wellburn, A.R. Determinations of Total Carotenoids and Chlorophylls a and $b$ of Leaf Extracts in Different Solvents; Portland Press Limited: London, UK, 1983.

50. Irigoyen, J.; Einerich, D.; Sanche-Diaz, M. Water stress induced changes in concentrations of proline and total soluble sugars in nodulated alfalfa (Medicago sativa) plants. Physiol. Plant 1992, 84, 55-60. [CrossRef]

51. Bradford, M.M. A rapid and sensitive method for the quantitation of microgram quantities of protein utilizing the principle of protein binding. Anal Biochem. 1976, 72, 248-254. [CrossRef]

52. Bates, L.; Waldren, R.P.; Teare, J.D. Rapid determination of free proline for water stress studies. Plant Soil 1973, 39, 205-207. [CrossRef]

53. Zhang, Z.L.; Qu, W.J. The Experimental Guide for Plant Physiology; Higher Edu. Press: Beijing, China, 2004.

54. Abdel Latef, A.A.; Tran, L.S.P. Impacts of priming with silicon on the growth and tolerance of maize plants to alkaline stress. Front. Plant Sci. 2016, 7, 243. [CrossRef]

55. Ahmad, P.; Abdel Latef, A.A.; Hashem, A.; AbdelAllah, E.F.; Gucel, S.; Tran, L.S.P. Nitric oxide mitigates salt stress by regulating levels of osmolytes and antioxidant enzymes in chickpea. Front. Plant Sci. 2016, 7, 347. [CrossRef]

56. Aebi, H. Catalase in vitro. Methods Enzymol. 1984, 105, 121-126. 
57. Maehly, A.C.; Chance, B. The Assay of Catalase and Peroxidase. In Methods in Biochemistry Analysi; Glick, D., Ed.; Interscience Publishers: New York, NY, USA, 1954; Volume 1, pp. 357-425.

58. Chen, G.-X.; Asada, K. Inactivation of ascorbate peroxidise by thiols requires hydrogen peroxide. Plant Cell Physiol. 1992, 33, 117-123.

59. Williams, V.; Twine, S. Flame photometric method for sodium, potassium and calcium. In Modern Methods of Plant Analysis; Springer International: Berlin, Germany, 1960; Volume 5.

60. Allen, S.E. Chemical Analysis of Ecological Materials 2; Blackwell: London, UK, 1989.

61. Feigl, G.; Kumar, D.; Lehotai, N.; Pető, A.; Molnár, Á.; Rácz, É.; Ördög, A.; Erdei, L.; Kolbert, Z.; Laskay, G. Comparing the effects of excess copper in the leaves of Brassica juncea (L. Czern) and Brassica napus (L.) seedlings: Growth inhibition, oxidative stress and photosynthetic damage. Acta Biol. Hung. 2015, 66, 205-221. [CrossRef]

62. Yruela, I. Copper in plants. Braz. J. Plant Physiol. 2005, 17, 145-146.

63. Ali, S.; Shahbaz, M.; Shahzad, A.N.; Khan, H.A.; Anees, M.; Haider, M.S.; Fatima, A. Impact of copper toxicity on stone-head cabbage (Brassica oleracea var. capitata) in hydroponics. Peer J. 2015, 3, 1119. [CrossRef]

64. Rehman, B.; Hassan, T.U.; Bano, A. Potential of indole-3-acetic acid-producing rhizobacteria to resist $\mathrm{Pb}$ toxicity in polluted soil. Soil Sediment Contam. Inter. J. 2019, 28, 101-121. [CrossRef]

65. Nayak, A.K.; Panda, S.S.; Basu, A.; Dhal, N.K. Enhancement of toxic Cr (VI), Fe, and other heavy metals phytoremediation by the synergistic combination of native Bacillus cereus strain and Vetiveria zizanioides $\mathrm{L}$. Int. J. Phytorem. 2018, 20, 682-691. [CrossRef]

66. Huang, H.; Zhao, Y.; Fan, L.; Jin, Q.; Yang, G.; Xu, Z. Improvement of manganese phytoremediation by Broussonetia papyrifera with two plant growth promoting (PGP) Bacillus species. Chemosphere 2020, 260, 127614. [CrossRef]

67. Gholami, A.; Biari, A.; Nezarat, S. Effect of seed priming with growth promoting rhizobacteria at different rhizosphere condition on growth parameter of maize. Inter. Meet. Soil Fert. Land Man. Agroclimatol. Turkey 2008, 851-856.

68. Biari, A.; Gholami, A.; Rahmani, H.A. Effect of different plant growth promotion bacteria (Azotobacter, Azospirillum) on growth parameters and yield of field maize. J. Water Soil Agric. Sci. Technol. 2011, 25, 1-10.

69. Anzuay, M.S.; Ciancio, M.G.R.; Ludueña, L.M.; Angelini, J.G.; Barros, G.; Pastor, N.; Taurian, T. Growth promotion of peanut (Arachis hypogaea L.) and maize (Zea mays L.) plants by single and mixed cultures of efficient phosphate solubilizing bacteria that are tolerant to abiotic stress and pesticides. Microbiol. Res. 2017, 199, 98-109. [CrossRef]

70. Lin, Y.; Watts, D.B.; Kloepper, J.W.; Torbert, H.A. Influence of plant growth-promoting rhizobacteria on corn growth under different fertility sources. Commun. Soil Sci. Plant Anal. 2018, 49, 1239-1255. [CrossRef]

71. De Sousa, S.M.; de Oliveira, C.A.; Andrade, D.L.; de Carvalho, C.G.; Ribeiro, V.P.; Pastina, M.M.; Gomes, E.A. Tropical Bacillus Strains Inoculation Enhances Maize Root Surface Area, Dry Weight, Nutrient Uptake and Grain Yield. J. Plant Growth Regul. 2020. [CrossRef]

72. Thounaojam, T.C.; Panda, P.; Mazumdar, P.; Kumar, D.; Sharma, G.D.; Sahoo, L.; Sanjib, P. Excess copper induced oxidative stress and response of antioxidants in rice. Plant Physiol. Biochem. 2012, 53, 33-39. [CrossRef]

73. Sharma, P.; Sirhindi, G.; Singh, A.K.; Kaur, H.; Mushtaq, R. Consequences of copper treatment on pigeon pea photosynthesis, osmolytes and antioxidants defense. Physiol. Mol. Biol. Plant 2017, 23, 809-816. [CrossRef]

74. Li, Q.; Chen, H.H.; Qi, Y.P.; Ye, X.; Yang, L.T.; Huang, Z.R.; Chen, L.S. Excess copper effects on growth, uptake of water and nutrients, carbohydrates, and PSII photochemistry revealed by OJIP transients in Citrus seedlings. Environ. Sci. Poll. Res. 2019, 26, 30188-30205. [CrossRef] [PubMed]

75. Saleem, M.H.; Rehman, M.; Kamran, M.; Afzal, J.; Noushahi, H.A.; Liu, L. Investigating the potential of different jute varieties for phytoremediation of copper-contaminated soil. Environ. Sci. Poll. Res. 2020. [CrossRef]

76. Parveen, A.; Saleem, M.H.; Kamran, M.; Haider, M.Z.; Chen, J.T.; Malik, Z.; Azeem, M. Effect of Citric Acid on Growth, Ecophysiology, Chloroplast Ultrastructure, and Phytoremediation Potential of Jute (Corchorus capsularis L.) Seedlings Exposed to Copper Stress. Biomolecules 2020, 10, 592. [CrossRef]

77. Zaouali, W.; Mahmoudi, H.; Salah, I.B.; Mejri, F.; Casabianca, H.; Hosni, K.; Ouerghi, Z. Copper-induced changes in growth, photosynthesis, antioxidative system activities and lipid metabolism of cilantro (Coriandrum sativum L.). Biologia 2020, 75, 367-380. [CrossRef] 
78. Hossain, M.S.; Abdelrahman, M.; Tran, C.D.; Nguyen, K.H.; Chu, H.D.; Watanabe, Y.; Tran, L.S.P. Insights into acetate-mediated copper homeostasis and antioxidant defense in lentil under excessive copper stress. Environ. Pollut. 2020, 258, 113544. [CrossRef]

79. Chrysargyris, A.; Papakyriakou, E.; Petropoulos, S.A.; Tzortzakis, N. The combined and single effect of salinity and copper stress on growth and quality of Mentha spicata plants. J. Hazard. Mater. 2019, 368, 584-593. [CrossRef]

80. Burd, G.I.; Dixon, D.G.; Glick, B.R. Plant growth-promoting bacteria that decrease heavy metal toxicity in plants. Can. J. Microbiol. 2000, 46, 237-245. [CrossRef]

81. Briat, J.F.; Fobis-Loisy, I.; Grignon, N.; Lobréaux, S.; Pascal, N.; Savino, G.; Van Wuytswinkel, O. Cellular and molecular aspects of iron metabolism in plants. Biol. Cell 1995, 84, 69-81. [CrossRef]

82. Kamran, M.A.; Syed, J.H.; Eqani, S.A.M.A.S.; Munis, M.F.H.; Chaudhary, H.J. Effect of plant growth-promoting rhizobacteria inoculation on cadmium (Cd) uptake by Eruca sativa. Environ. Sci. Poll. Res. 2015, 22, 9275-9283. [CrossRef]

83. Al Khateeb, W.; Al-Qwasemeh, H. Cadmium, copper and zinc toxicity effects on growth, proline content and genetic stability of Solanum nigrum L., a crop wild relative for tomato; comparative study. Physiol. Mol. Biol. Plants 2014, 20, 31-39. [CrossRef] [PubMed]

84. Sharma, R.; Bhardwaj, R.; Thukral, A.K.; Al-Huqail, A.A.; Siddiqui, M.H.; Ahmad, P. Oxidative stress mitigation and initiation of antioxidant and osmoprotectant responses mediated by ascorbic acid in Brassica juncea L. subjected to copper (II) stress. Ecotoxicol. Environ. Saf. 2019, 182, 109436. [CrossRef]

85. Khan, N.; Bano, A. Role of plant growth promoting rhizobacteria and Ag-nano particle in the bioremediation of heavy metals and maize growth under municipal wastewater irrigation. Int. J. Phytorem. 2016, 18, $211-221$. [CrossRef]

86. Zhang, M.; Jin, Z.; Zhang, X.; Wang, G.; Li, R.; Qu, J.; Jin, Y. Alleviation of Cd phytotoxicity and enhancement of rape seedling growth by plant growth-promoting bacterium Enterobacter sp. Zm-123. Environ. Sci. Poll. Res. 2020, 27, 33192-33203. [CrossRef]

87. Khanna, K.; Jamwal, V.L.; Sharma, A.; Gandhi, S.G.; Ohri, P.; Bhardwaj, R.; Ahmad, P. Supplementation with plant growth promoting rhizobacteria (PGPR) alleviates cadmium toxicity in Solanum lycopersicum by modulating the expression of secondary metabolites. Chemosphere 2019, 230, 628-639. [CrossRef] [PubMed]

88. Mesa-Marín, J.; Del-Saz, N.F.; Rodríguez-Llorente, I.D.; Redondo-Gómez, S.; Pajuelo, E.; Ribas-Carbó, M.; Mateos-Naranjo, E. PGPR reduce root respiration and oxidative stress enhancing spartina maritima root growth and heavy metal rhizoaccumulation. Front. Plant Sci. 2018, 9, 1500.

89. Islam, F.; Yasmeen, T.; Ali, Q.; Mubin, M.; Ali, S.; Arif, M.S.; Abbas, F. Copper-resistant bacteria reduces oxidative stress and uptake of copper in lentil plants: Potential for bacterial bioremediation. Environ. Sci. Poll. Res. 2016, 23, 220-233. [CrossRef]

90. Khanna, K.; Jamwal, V.L.; Gandhi, S.G.; Ohri, P.; Bhardwaj, R. Metal resistant PGPR lowered Cd uptake and expression of metal transporter genes with improved growth and photosynthetic pigments in Lycopersicon esculentum under metal toxicity. Sci. Rep. 2019, 9, 1-14. [CrossRef]

91. Fatnassi, I.C.; Chiboub, M.; Saadani, O.; Jebara, M.; Jebara, S.H. Impact of dual inoculation with Rhizobium and PGPR on growth and antioxidant status of Viciafaba, L. under copper stress. C. R. Biol. 2015, 338, 241-254. [CrossRef]

92. Ju, W.; Liu, L.; Fang, L.; Cui, Y.; Duan, C.; Wu, H. Impact of co-inoculation with plant-growth-promoting rhizobacteria and rhizobium on the biochemical responses of alfalfa-soil system in copper contaminated soil. Ecotoxicol. Environ. Saf. 2019, 167, 218-226. [CrossRef]

93. Marschner, H. Mineral Nutrition of Higher Plants, 2nd ed.; Academic: San Diego, CA, USA, 1995.

94. Ali, N.A.; Bernal, M.P.; Ater, M. Tolerance and bioaccumulation of copper in Phragmites australis and Zea mays. Plant Soil 2002, 239, 103-111. [CrossRef]

95. Azeez, M.O.; Adesanwo, O.O.; Adepetu, J.A. Effect of Copper (Cu) application on soil available nutrients and uptake. Afr. J. Agric. Res. 2015, 10, 359-364.

96. Zhou, C.; Guo, J.; Zhu, L.; Xiao, X.; Xie, Y.; Zhu, J.; Wang, J. Paenibacillus polymyxa BFKC01 enhances plant iron absorption via improved root systems and activated iron acquisition mechanisms. Plant Physiol. Biochem. 2016, 105, 162-173. [CrossRef]

97. Timmusk, S.; Nicander, B.; Granhall, U.; Tillberg, E. Cytokinin production by Paenibacillus polymyxa. Soil Biol. Biochem. 1999, 31, 1847-1852. [CrossRef] 
98. Lebuhn, M.; Heulin, T.; Hartmann, A. Production of auxin and other indolic and phenolic compounds by Paenibacillus polymyxa strains isolated from different proximity to plant roots. FEMS Microbiol. Ecol. 1997, 22, 325-334. [CrossRef]

99. Saeid, A.; Prochownik, E.; Dobrowolska-Iwanek, J. Phosphorus solubilization by Bacillus species. Mol. (Basel Switz.) 2018, 23, 2897. [CrossRef]

100. Montañez, A.; Blanco, A.R.; Barlocco, C.; Beracochea, M.; Sicardi, M. Characterization of cultivable putative endophytic plant growth promoting bacteria associated with maize cultivars (Zea mays L.) and their inoculation effects in vitro. Appl. Soil Ecol. 2012, 58, 21-28. [CrossRef]

101. Ferreira, M.H.; Sorares, H.M.V.M.; Soares, E.F. Promising bacterial genera for agricultural practices: An insight on plant growth-promoting properties and microbial safety aspects. Sci. Total Environ. 2019, 682, 779-799. [CrossRef]

Publisher's Note: MDPI stays neutral with regard to jurisdictional claims in published maps and institutional affiliations.

(C) 2020 by the authors. Licensee MDPI, Basel, Switzerland. This article is an open access article distributed under the terms and conditions of the Creative Commons Attribution (CC BY) license (http://creativecommons.org/licenses/by/4.0/). 